\title{
Vulnerabilities of wheat crop farmers in war zone
}

\author{
Stanikzai, A.N., "Ali, F. and Kamarulzaman, N.H. \\ Department of Agribusiness and Bioresource Economics, Faculty of Agriculture, Universiti Putra Malaysia, \\ 43400 UPM Serdang, Selangor, Malaysia
}

\begin{abstract}
Article history:
Received: 11 September 2020 Received in revised form: 21 October 2020

Accepted: 17 December 2020 Available Online: 11 April 2021
\end{abstract}

\section{Keywords:}

Farmers' vulnerabilities,

Wheat crop production,

War zone,

Afghanistan

\section{DOI:}

https://doi.org/10.26656/fr.2017.5(2).506

\begin{abstract}
Wheat is the staple food crop in Afghanistan and maintaining its production plays important role in ensuring food security and food self-sufficiency. Wheat and its products are accounted for almost $60 \%$ to $75 \%$ of calories intake. However, being a country that has been facing war since 1978, it has been challenging for the wheat production industry to maintain its production to feed its people. Hence, the purpose of this study is to investigate wheat crop industry players' vulnerabilities in the production of the wheat crop in a prolonged war zone. The study is conducted through the case study approach. Required data was collected through interviews, observations and documents which was analyzed through thematic analysis. This study found that in addition to the normal vulnerabilities/issues faced by the wheat crop industry players in the world, the players in the war zone have to face psychological effects, and financial corruption as well.
\end{abstract}

\section{Introduction}

Afghanistan's agricultural sector accounted for around $23 \%$ of the domestic GDP in 2017 and is the second biggest after the service sector (Central Statistics Organization of Afghanistan, 2019). The agriculture sector plays a significant part in people's livelihoods and more than $80 \%$ of Afghanistan's population is engaged directly or indirectly in the industry (World Bank, 2014). About half of all Afghan families earn at least a portion of their revenue from agriculture and employ about $40 \%$ of the workforce in the country (World Bank, 2014). It benefits Afghan women, disadvantaged groups (poor, landless and nomads) and offers workforce opportunities to improve their productivity and decrease poverty and food insecurity in villages (World Bank, 2014). Cereal and other annual field crop production are the main agricultural activities in Afghanistan, which accounted for approximately $37 \%$ of the overall agricultural GDP in 2017. Wheat production is the biggest share of this aspect (i.e. one-quarter of GDP in agriculture) (Central Statistic Organization, 2019). Wheat is the staple food crop in Afghanistan and maintaining its production plays important role in ensuring food security and food selfsufficiency. Due to mountainous land in most of the country and arid to semi-arid climate, crops are grown on only around $14 \%$ of the overall land. Approximately $70 \%$ of the overall crop cultivated land is grown with wheat crops (Chabot and Dorosh, 2007). Wheat and its products are accounted for almost $60 \%$ to $75 \%$ of calories intake in Afghanistan (World Bank, 2005).

Pre-war (before the Soviet Union occupation), Afghanistan was self-sufficient in wheat and even exported the wheat surplus to other countries. Today, however, the country imports an average of 1.2 million $\mathrm{mt} / \mathrm{year}$ due to the decline in wheat production caused by war (World Bank, 2014). While Afghanistan was selfsufficient in pre-war wheat production in 1974 (Wesa, 2002), production worsened during years of conflict owing to the combined impacts of extended droughts and the devastation of irrigation channels and infrastructure. First, the devastation caused by the conflict between the Afghans and the Soviet forces, then the civil war following the Soviet withdrawal in 1989 (Chabot and Dorosh, 2007; Persaud, 2013). The declining trend of wheat production continued further during the civil war from 1989-2001. In 2001, after the invasion of Afghanistan by America, the deficit between wheat crop production and consumption increased. Meanwhile, imports of wheat from outside the country increased. Four decades of continuous war, social unrest, continuous movements of returnees, civil strife, insurgent activity, and frequent natural disasters left people in a dire situation and have led Afghanistan to chronic humanitarian need. The primary drivers of 
chronic food insecurity in Afghanistan are widespread war, bad rain-fed staple production and restricted employment opportunities (USAID, 2020). Thus, this study will focus on the impacts of war and farmers' vulnerability in the production of wheat crop production in the war zone.

The notion of vulnerability has become a strong analytical approach to determine levels of susceptibility to threat, impotence and marginalization in both social and physical structures, and to direct the normative assessment of behaviour to improve wellbeing through risk reduction (Adger, 2006). Vulnerability is commonly viewed as the susceptibility to harm in negative terms. The core concept behind the frequently quoted definition of the Intergovernmental Panel on Climate Change (IPCC) is that vulnerability is a degree to which a system is sensitive and unable to cope with detrimental consequences (McCarthy et al., 2001). Vulnerability is seen as a susceptibility to danger, a potential for system change or transformation when faced with disruption, rather than as the result of that confrontation. Diverse views on the exact meaning of vulnerability, however, are also apparent (Gallopín, 2006). Peck (2006) states something that is "at risk, is vulnerable". Pettit et al. (2010) defined vulnerability from the perspective of the organization. According to Pettit et al. (2010), vulnerability constructs are "fundamental factors that make an enterprise susceptible to disruptions".

Through the literature review, it was found that most of the scholars focused on understanding farmers vulnerabilities/issues from two perspectives of climate change and accessibility to agriculture inputs in peaceful and the war zone. In the first part of vulnerability literature, scholars (Zarafshani et al. 2012; Harvey et al. 2014; Gwimbi, 2009; Thorlakson and Neufeldt, 2011) have looked at if the farmers are vulnerable to the adverse impacts of climate change. In the second part of farmers' vulnerability literature particularly farmers' accessibility to inputs in peaceful zones, scholars (Shiferaw et al., 2008; Girabi and Mwakaje, 2013, Liverpool-Tasie, 2014; Ibrahim and Aliero, 2012; Owolabi et al., 2011; Anaglo et al., 2014) have looked at if the farmers have access to agriculture extension services, credit, and inputs. On the other hand, a number of studies have been conducted on studying farmers' vulnerabilities in the post-war zone. Literature review shows most of the scholars have studied farmers vulnerabilities from the perspective of food security (Awodola and Oboshi, 2015; Kah, 2017) and the effects of conflict on agriculture production (Jaafar et al., 2015; Adelaja and George, 2019) in conflict/war zone.
In the literature of farmers' vulnerability, the abovementioned findings seem consistent. All of these studies focused on the vulnerability of farmers toward climate changes, its effects on agriculture production and farmers' accessibility to agriculture inputs in the peaceful and post-war zone. Less is known about farmers vulnerabilities in practising agriculture activities in an active/ongoing and long-lasting war zone. Thus, the present study is attempting to look at the vulnerabilities famers face in active war zone by employing qualitative case study approach.

\section{Materials and methods}

The study was aimed to understand the vulnerabilities of farmers in the production of wheat crop in the war zone through the experiences of individual farmers/cooperative members, and extension officers. This study was conducted through qualitative case study research. This study was carried out in five provinces (Kapisa, Kunduz, Logar, Parwan, and Panjshir) of Afghanistan. The five provinces were selected based on the effects of war they observed during the different times of war i.e. Soviet Union occupation, civil war and currently the American invasion. To collect data, snowballing technique was employed. The informants were involved in the wheat crop industry and have been affected by war (Soviet Union occupation, civil wars, and American invasion). Individual farmers and cooperative members are involved in the production of the wheat crop while extension officers are providing agricultural extension services to them.

A total of twenty-three all-male informant participated in the interviews. Five of the informants were agriculture department officers, one from each province. Six of the informants were Cooperatives members from different cooperatives in all five provinces. The rest of the informants which makes 12 persons were farmers from the five provinces. The criteria for selecting the informants were that 1) All selected informants should be involved in the wheat crop industry 2) Should be in a war zone or affected by war directly or indirectly or to be conversant in the subject matter.

As such, in-depth (face to face) interviews were used by the researcher to obtain data from the informants involved in the wheat crop industry. All of the interviews were conducted from August 2018 to October 2018. The interviews were conducted with a mixture of Pashto and Dari (both local and national) languages of the country as the informants were speaking it in different provinces and location. Each interview lasted between thirty-five minutes and two-hours. The researcher obtained the "real 
-life" experiences of the informants in gaining more valid information through in-depth interviews. Information was collected till saturation point. Apart from interviews, observations were made during case sites visiting.

Data analysis began with interviews transcription. The interviews were transcribed in Pashto and Dari languages. Nearly 19 hours of interviews produced 120 single-spaced typewritten pages for analysis. Transcribed interviews were divided into three groups of farmers, cooperative members and extension officers (agricultural department officers). All three groups of transcribed interviews together with field notes from observations, pictures and videos were loaded to NVIVO 12 software for analysis. All interviews transcripts were read line by line and needed data were extracted and coded in the codebook of the NVIVO 12 software. During the open coding process, 198 open codes appeared for cooperative members, 180 for farmers and 174 for agriculture department officers. All open codes were later categorized into seven vulnerability constructs of the framework. In addition to the examination of the framework constructs, this study found two new vulnerability constructs which did not exist before.

\section{Results}

This section discusses the vulnerabilities that individual farmers, cooperative members and extension officers face in their effort of production of wheat crop in the war zone. Vulnerabilities include turbulence, deliberate threats, external pressure, resource limits, sensitivity, connectivity, and customer/supplier disruption which is presented below.

\subsection{Turbulence}

Geopolitical disruption, war and instabilities in Afghanistan has been a major challenge for the agriculture sector. This problem has severely affected the development of the agriculture sector since the occupation of the country by the Soviet Union in 1979. Throughout these decades of war, SUO (Soviet Union occupation 1979-1989), civil war (1989-2001), and American invasion (2001 up to date), the agriculture sector especially the wheat crop industry across the country has not been able to thrive back to the success they achieved before the war (pre-1978). The conflict between foreign invaders and resistance has put the agriculture sector in a dire situation throughout four decades of war. The existence of militants/troops in rural areas and war zone disrupts the development of the agriculture sector. Due to the omnipresence of militants/ troops, the extension officers and farmers are unable to work freely on the fields. This has raised issues related to agriculture such as low access to farms, limited access to market, low access to agriculture equipment, and untimely farming activities in the area. According to the extension officers (Extension Officer 2 and 1) interviewed, the Mujahedeen (armed opposition of Afghan government during SUO) were everywhere and were prohibiting the extension officers from going to the wheat field to meet farmers. If the extension officers were captured by Mujahedeen in the area under their control, most of the time, the officers get killed by Mujahedeen. Inaccessibility to the field resulted in the increase of diseases, avoided transmission (diffusion) of new agricultural technologies amongst farmers and declined wheat production. This is further elaborated by Extension Officers 2 and 1:

"During the SUO, the armed oppositions of the government did not allow the government staffs to conduct their duties" (Extension Officer 2, 29 August 2018).

"During the SUO, the agriculture department could not provide extension services to the farmers because we had a war here [in Panjshir province]. We could not access the farmers and almost all governmental administrations were shutdown..." (Extension Officer 1, 26 August 2018).

Similarly, farmers also face accessibility restriction in the field. Farmers cannot freely work on their farms because they are afraid that they might get killed. In other words, farmers cannot go to farms to cultivate, irrigate, weed, control diseases, and harvest their output on time because if they go in such conditions, they will get killed or may get injured. This scenario is best described by a farmer (Farmer 5) from Panjshir province when he recalled SUO:

"In the war zone, due to the existing risk of war, farmers cannot go to the farmlands and cannot proceed with farming activities such as irrigation, cultivation, and harvesting. They fear that something will happen to them" (Farmer 5, August 26, 2018).

According to a cooperative member (Cooperative Member 6), inaccessibility to the field causes untimely agriculture practices which result in output reduction. He further said:

"Farmers cannot get improved seeds from the department of agriculture because farmers cannot come to the city and cannot take it back to villages.... Farmers cannot irrigate or spread chemical fertilizer within the needed time. Once I decided to spread chemical fertilizer in the morning, the same morning war happened and lasted for one week... if farmers do not reap and cultivate on time, the output will decrease by 
half" (Cooperative Member 6, September 21, 2018).

Geopolitical disruption also limits the accessibility of farmers to market in the war zone. In this case, traders do not trade in the war zone. Breakdown of the trader's relationship with farmers in war zone affects the price of wheat crop produces. Hence, farmers are unable to sell their output even at a lower price as explained by a farmer (Farmer 1) below. Lower price for wheat in war zone makes farmers to convert from wheat crop cultivation to other crop cultivation (i.e. poppy) which is a more lucrative and good source of income for farmers. Therefore, Afghanistan is considered the highest producer of opium in the world. According to a report from the United Nation Office on Drugs and Crime (2018), global opium production reached its peak in 2017 with over 10,000 tons. Ninety percent of the opium produced in Afghanistan, a record level of production rendering Afghanistan the leading producer of opium in the world.

"Currently, if the situation is not good in an area [war zone] or people hear the sound of gunfire, then traders will not try to go there...so let say if the price of the product is 200 AFG in the market, we can't even sell it for $150 \mathrm{AFG}$ because of the chaos...traders are afraid of the risk posed to their life." (Farmer 1, September 3, 2018).

Price of output and input fluctuate when there are geopolitical instabilities. This price fluctuation severely affects both producer and consumer of agriculture products. The price fluctuates due to the unavailability of inputs and limited access to the input/output market in the war zone. In the war zone, inputs are unavailable due to inaccessibility to market, roads block, ban on specific chemical fertilizers (Urea or Ammonium nitrate), fear due to the destruction and burning of the machinery (tractors, thrashers) and killing of labourers. In this regard, a cooperative member (Cooperative Member 6) from Kunduz province said:

"We have so many problems regarding technology. The owners of the machinery [tractors, threshers] that we use, do not let us rent the machinery in a war zone or [if they happen to allow us to rent, we] have to pay twice more than [those farmers at the] peaceful zones because the machinery can be set to fire in war. So, the owner is demanding twice more money [from us compared to] peaceful areas (Cooperative Member 6, September 21, 2018).

Further, War paves the way for an increased incidence of plant diseases. In the war zone, plant diseases increase due to contamination of land by remnants of war (i.e. chemical, and gunpowder), and the existence of low-quality pesticides in the market. To shed light on this, a farmer (Farmer 3) from Parwan province said:

"Previously [before SUO], there was not that many plant diseases.... Currently, these diseases and pest reached to the level where it is inhibiting the growth of the wheat crop, vegetables and fruits. Diseases have increased $80 \%$ than before [i.e. during SUO]. Maybe it is caused by natural disaster, use of chemical gases and gunpowder in the war zone or it is because of the environment destruction [by war]" (Farmer 3, August 29, 2018).

\subsection{Deliberate threats}

There are stories in the war zone where a specific group of militants i.e. Soviet Union troops deliberately terrorized people and farmers/villagers in order to force them to abandon villages and farms. By terrorizing civilians, they were trying to destroy the supportive structure of their opposition among society. For example, Soviet Union troops were bombing the villages in order to destroy the supportive structure of their armed opposition (Mujahedeen). To further elaborate it, a farmer (Farmer 4) recalled his memory from SUO, he said:

"Once during Soviet Union Occupation (SUO) time, we cultivated wheat crop in our land. At the same time, Russian troops attacked our village. We left our homes and farms. They (Russian troops) set our wheat farms on fire and burned it" (Farmer 4, August 26, 2018).

Similar to farmers and villagers, extension officers and aid worker who provide agriculture services to farmers also face violence. A good example can be the assassination of a Japanese aid worker (doctor Tetsu Nakamura) who was working on an agriculture irrigation project in Nangarhar province. He was assassinated together with his five Afghan colleagues on $5^{\text {th }}$ December 2019. These scenarios sabotage the extension relationship between farmers and the agriculture department and leave the agriculture sector in a dire situation. In this regard Extension Officer 4 said:

"In the previous years, I witnessed two of our extension officers in the field were kidnapped and detained by the Taliban but were released later with the mediation of elders. This risk constrained extension officers to directly access farmers and the field. As a result, farmers faced increased problems in the field and that prevented the development of the wheat crop industry" (Extension Officer 4, September 20, 2018).

There are many stories where a special interest group (militant group) has used the civilian property as shelter 
(to hide) and as an ambush site to attack their opposition which in the result of fire exchange, the property has been destroyed as well as caused civilian casualties. It is further elaborated by Cooperative Member 6 from Kunduz province in an interview. He revealed:

"Once [in 2015] Taliban took ambush and fired on the governmental troops from our cooperative office. Before the war happened, I was only able to pull some equipment out of the office but others left inside. Later in the fire exchange between Taliban and government forces as well as in the bombardment, everything was destroyed and lost (Cooperative Member 6, 21 September 2018).

Another issue that restricts the access of farmers and traders to each other and the market is the existence of theft and robbery in the war zone. Due to this problem, traders cannot freely access farmers to buy their outputs in the war zone. If traders go to the war zone, there is a possibility that they may be kidnapped or robbed. Therefore, they avoid doing business in the war zone. In this regard, a farmer (Farmer 5) from Panjshir province said:

"...drug addicts steal when they do not have money to buy their drugs. We witnessed many theft and robbery cases during current time as well as during SUO” (Farmer 5, August 26, 2018).

\subsection{External pressure}

External pressure such as environmental changes, social changes and price pressure are factors that constrained wheat crop industry development during SUO, civil war and American invasion in all fiveprovinces studied. War and instabilities make the environment unfavourable for cultivation. Farmers cannot go out to grow wheat crops, taking care of the farms and harvest their outputs. They are afraid that either they will be stuck in war or will be killed. This scenario forces villagers and peasants to migrates from their lands and take shelter in peaceful areas which gradually disrupt agricultural development and destroy the societal structure in the war zone. As a result, production decreases and hunger are inflicted in areas affected by the war. Farmer 7 from Panjshir province described the social and environmental changes that happened to their villages during SUO:

"When it is war (bombardment and firing) in our surrounding area, we cannot go out to cultivate. For example, during the SUO, we could not go out to cultivate because they (Russian troops) were shelling artillery and bombing our villages. We took shelter in the mountains outside our village. We were residing in the mountains and could not go back to our homes. We were smuggling food for ourselves from other provinces through mountainous ways and people were cultivating crops only in areas that were out of Russian troops reach" (Farmer 7, August 27, 2018).

The scenario of social changes is further described by Cooperative Member 6 from Kunduz province. He stated:

"... when our cooperative and house were destroyed in the war between the Taliban and government, the government forces made a check-point in my house and the cooperative yard. I and my brother's family together with 5 or 6 other families left the village and migrated to Kunduz city. We commute daily between Kunduz city and our village in order to practice agriculture. This has caused problems in cultivation and other agricultural practices. Like me...other cooperative members who were in danger also left their villages and homes and migrated to other places." (Cooperative Member 6, September 21, 2018).

War affects farmers through high price pressure. The higher price of inputs affects agriculture production. In an interview with Farmer 4 in Panjshir province, it was revealed that farmers must pay a higher price for using farming machinery (i.e. tractor, thrasher) since it is not available in their areas. He commented:

"Our main problem is inaccessibility to subsidized inputs such as chemical fertilizer, improved seeds and machinery. We bring machinery from other provinces to which we pay a lot of money. Before [prior the extension of new technologies] we were using bulls instead of machinery, but now bulls are no longer available" (Farmer 4, August 26, 2018).

Cooperative Member 6 from Kunduz province added that no supply of wheat to markets forces local producers to sell their output with low prices in farm straight after harvesting it since farmers do not have access to markets and do not have storages to preserve the produce for a longer time. This case pave way for subsistence farming in the war zone. He elaborated:

"When we harvest our output, we are forced to sell it cheaply right away. Since we do not have storage to store it, traders buy it at the price they like ... then these local traders store it in their storages and sell it later with good prices" (Cooperative Member 6, September 21, 2018).

In addition to the social changes and price pressure, war makes the agricultural environment unfavourable for agriculture production. A farmer (Farmer 9) from Kapisa province complained that his agricultural lands became uncultivatable due to war (during SUO) and its 
remaining such as gunpowder. He said that not only his agricultural lands lost fertility, but he also cannot even cultivate pepper crop in his land anymore. He said:

"Before the SUO, we were harvesting a decent yield of pepper from our land. During the SUO, the Russian bombed our lands/farms until they completely turned black. After that, when we were cultivating pepper crop in the whole district of (Kohistan), the crops were dying and not growing. Now all these existing pest and plant diseases are the results of the Russian gunpowder and war. Now I can tell you that the incidence of plant diseases has tripled compared to the pre-SUO era" (Farmer 9, August 28, 2018).

\subsection{Resource limits}

In the war zone, farmers typically face a shortage of agricultural inputs/raw materials (certified seeds, chemical fertilizer, pesticides, and water) due to limited supply and suppliers, as well as human resources required for production. In the war zone, inputs are unavailable due to roads blockage, a ban on specific chemical fertilizers (Urea or Ammonium nitrate), fear due to the destruction and burning of the machinery (tractors, thrashers) and killing of labourers. During the interview, Farmer 3 from Parwan province recalled his experience during the Taliban time. He said:

"During the Taliban regime, they (Taliban) blocked all the roads and were not allowing people to carry the chemical fertilizer. When the chemical fertilizers were seized by the Taliban, they were pouring (throwing) them into the water stream. In that situation, we were cultivating without using chemical fertilizer. Sometimes we were using animal manure but animal manure cannot replace the chemical fertilizers" (Farmer 3, August 29, 2018).

In addition to the unavailability of raw materials (i.e. certified seeds, and chemical fertilizer), the war zone also faces a shortage of labour (human resource) needed for the production process. It happens due to the mass migration of residents from active war zone to relative peaceful areas. Because of this scenario, most of the farms and villages are vacated (without people/farmers) in the war zone. Those farmers who left behind/not migrated face labour shortage because labourers/farmers do not want to put themselves in danger to work/ cultivate in the war zone. This situation severely affects the production level of wheat crop in the war zone. In this regard, Cooperative Member 6 from Kunduz province said:

"Previously we had a culture called Hashar (Gathering). A group of 10,20 , or 30 people were gathering and working together. Currently everybody is working for themselves because due to war, the area is insecure, and no one can assuredly invite someone to work (help) with us. For example, if I want to invite others to help, 100 people will come to help, but I am afraid that if a blast happens all will be dead or injured. For this reason, we have cancelled the Hashar (gathering system), but the Hashar system still exists wherever it is peaceful" (Cooperative Member, September 2018).

Unfavourable condition (war) and lack of production resources (agricultural inputs) in war zone reduce farmers production capacity. The production capacity (production level) declined substantially since farmers cannot cultivate, take care of the crops (control of weeds and plant diseases), irrigate their farms and harvest on time due to war as well as the lack of labour forces. In the current invasion by America, the same scenario (untimely farming due to war) that happened during the SUO time is happening in Kunduz province as described by a cooperative member (Cooperative Member 6). He further revealed:

"I was harvesting 25 to 27 tons of rice and 17 to 20 tons of wheat from four hectares of my lands before [a few years back]. Now from the same size of land, I could only harvest 8.4 to 9 tons of wheat. I spent around 2200 US\$ to produce it. Now, if you compare wheat income with wheat costs, you will see that it only breaks even. All people suffer from the same problem... war has a negative impact on agriculture. When you cannot work in the field, cannot harvest, control weed, and irrigate on time, it definitely affects the production" (Cooperative Member 6, September 21, 2018).

\subsection{Sensitivity}

In the war zone, farmers are extremely sensitive to the quality of agricultural inputs (equipment reliability) and their safety (safety hazard). The quality of inputs directly affects production. Nowadays, the quality of inputs (equipment reliability) is a major issue in Afghanistan. Almost four decades of continuous war (SUO, civil war, America invasion) and instabilities has resulted in low quality of inputs. Controlling the quality during the war and instability pose a challenge for the agricultural ministry, particularly in remote areas or areas out of government control. Besides, the existence of financial corruption in governmental administrations has paved way for the low-quality agricultural inputs in the markets. Low quality of inputs such as seeds, chemical fertilizer and pesticides decrease production. To enlighten this, Cooperative Member 1 said:

"One thing revealed after the SUO is the changes in the quality of improved seeds.... Even though they (Agriculture Ministry) argue that these [seeds supplied to 
farmers by the agriculture department] are improved seeds, production is lower. Also, when we cook it at home, it [bread] has no quality" (Cooperative Member 1, August 26, 2018).

To describe the quality of chemical fertilizer, Farmer 9 from Kapisa province reported his own experiment regarding DAP (Diammonium Phosphate). He further said:

“...To experiment, once I added seven kilograms of DAP fertilizer to a single pepper crop, even that huge amount of fertilizer had no negative effects on that crop. Not even its leaves got burned, nor its height got affected. So, we have these kinds of chemical fertilizer in our country that has no quality" (Farmer 9, August 28, 2018).

In addition to the input's quality (equipment reliability), farmers safety (safety hazard) is also an issue in the war zone. Working on the field in the active war zone is a dangerous job. The safety of farmers, extension officers and traders in the war zone prevent them to accomplish agriculture-related activities. According to Cooperative Member 3 from Parwan province, the safety of wheat crop producer in war zone affects wheat crop production:

"Due to severe war and bombardment in rural areas during SUO, $50 \%$ of the production diminished. Russian was bombing agricultural lands, and people were forced to flee. During the Taliban regime (civil war), vineyards and gardens trees were being cut.... Because of the bombing and war, $50 \%$ of the production diminished" (Cooperative Member 3, August 29, 2018).

\subsection{Connectivity}

The Degree of connection and reliance of farmers on each other and outside sources is crucial for the development of the agriculture sector. In the war zone, there is no or very poor extension relationship between farmers and the department of agriculture. As we mentioned in the explanation of deliberate threat constructs above, due to war and threats imposed on the life of agriculture extension officers, they do not have access to the field or they are indirectly in touch with farmers through local elders. During the different time of war such as SUO, civil war and the current American invasion, extension officers were kidnapped many times. Sometimes, they were only detained and then released back with the mediation of local figures, but in other times, they were killed by the militants. In recent time, according to an extension officer (Extension Officer 4) from Kunduz province, two of their extension officers were kidnapped by the Taliban but later released with the mediation of local elders. He said:

"In previous years, I witnessed that two of our extension officers in the field were kidnapped and detained by the Taliban, but later with the mediation of elders were released. This risk limits the direct access between the extension officers with the farmers and the field. This leads to increased problems for the farmers in the field that prevent the development of the wheat crop industry" (Extension Officer 4, September 20, 2018).

Extension Officer 4 further added that two of extension officers were kidnapped and killed in Logar province a few years back: "...We heard and witnessed that in some other provinces [Logar], agriculture extension officers were kidnapped and killed". These incidents have imposed danger to the life of extension officers and constrained extension officers to visit the field. The absence of extension officers increased plant diseases in the field which resulted in production decline. Similarly, due to the breakdown of the extension relationship, the department of agriculture is not able to deliver new technology to the farmers' community in order to increase production in the war zone.

\subsection{Customer/Supplier disruption}

In the war zone, farmers find it hard and even some times impossible to find traders to buy their produce (wheat) or to sell their output in the markets due to the customer disruption caused by war. Traders could not go to the rural areas to buy farmers' outputs because of the risk threatening their lives in the war zone. This situation has constrained farmers from production based on market demand/commercial agriculture in the war zone. Therefore, most of the farmers practise subsistence agriculture in the war zone. For example, Farmer 1 from Logar province who has been cultivating wheat for 18 years, mentioned that war especially when there is military operation/ambush, affects their ability to sell their output:

"Currently, if the situation is not good in an area [war zone] or people hear the sound of gunfire, then traders will not try to go there...so let say if the price of the product is $200 \mathrm{AFG}$ in the market, we can't even sell it for 150 AFG because of the chaos...traders are afraid of the risk posed to their life." (Farmer 1, September 3, 2018).

In addition to customer disruption, in war zone farmers cannot rely much on the supplier for supplying them agriculture inputs. The supplier cannot supply inputs on time due to transport restrictions/roadblocks caused by war. This case affects farmers accessibility to agriculture technologies. This scenario is best described 
by Farmer 7 from Panjshir province. He described their relationship with input suppliers during SUO in Panjshir:

"During the wartime [SUO], suppliers were not coming to the area [Panjshir province] to provide us with the inputs because they were afraid that they would get killed. On the other hand, during peaceful time everything can be done, and suppliers are also confident of supplying to [inputs] us" (Farmer 7, August 26, 2018).

\subsection{New found Constructs}

In addition to the seven vulnerability constructs of supply chain resilience framework described above, two more new constructs are found in this study that was not covered in the framework used in this research. These constructs are: 1) Psychological Effects/Fear, and 2) Corruption/Financial corruption. The data reveals that these two constructs are quite prominent in the context of this research. Evidence are further elaborated below:

\subsubsection{Psychological effects: fear}

War and working in the war zone have several implications. Besides the physical destruction of infrastructure (roads, buildings, dams, irrigation canals) and human casualties, war creates fear among those residing or working in the war zone. Due to severe and prolonged war conditions and fear, farmers cannot proceed with agricultural activities, extension officers cannot go to the field to solve farmers' problems and traders cannot access farmers to buy their outputs. There is no or very poor extension relationship between farmers and department of agriculture when fear exists among extension officers. It has also happened many times that a civilian or a farmer has become a sacrifice of war. In an interview, a farmer (Farmer 11) from Kapisa province revealed that due to the fear of being killed, farmers cannot work freely in their farms, sometimes it even pressures the farmers to leave farming and migrate to other places. He said:

"When it is war, no one can do farming because if we go to the farm, we will get killed. Therefore, due to the fear of getting killed, no one will go to the farm to irrigate. Also, farmers cannot harvest due to security restriction. When no one can go to the farm, then there is no cultivation and production" (Farmer 11, August 28, 2018)

Similarly, another farmer (Farmer 9) from Kapisa province recalled his experience of conducting agricultural activities during SUO. He said:

"It was very difficult to cultivate during SUO since the army base was on the top of a mountain adjacent to our home. Thus, we could not reap the wheat during the daytime. Instead, we were reaping it at nighttime or early in the morning before morning prayer" (Farmer 9, August 28, 2018).

Similar to farmers, traders also fear/concern about getting killed or kidnapped during trading inputs and outputs in the war zone. This scenario caused unavailability of inputs and no accessibility of farmers to the output market. In this regard, a farmer (Farmer 1) from Logar province described the existence of fears amongst traders during the America invasion.

"At present, if the situation is not good in an area [war zone] or people hear the sound of gunfire, then traders will not try to go there...traders are afraid of the risk posed to their life." (Farmer 1, September 3, 2018).

\subsubsection{Financial corruption}

In addition to the destruction, and psychological effects (fear), war paves the way for corruption. First, war causes the increasing of corruption in governmental administrations. In the case of war, most of the financial resources are used in financing war instead of economic development and paying a good salary for governmental employees. Lower salary and higher family needs pushed governmental employees to seek bribery while conducting their duties. Second, because of the war and insecurity, responsible administrations could not monitor the quality of inputs and outputs, especially in areas that are not in control of the government or in the war zone. Lack of monitoring provides an opportunity for those involved in the agricultural input's (i.e. certified seeds, chemical fertilizers, and pesticides) market to get involved with corruption and supply low-quality inputs. In this scenario, farmers are the ones that are directly affected by the existence of financial corruption in the inputs market in the war zone. From the quote below, one can see that the reason for the decline in input quality is financial corruption which came to existence as a result of four decades of continuous war. The corruption situation came to existence as the country was occupied by SU, and it has become the culture among the extension officers/government authorities and traders during the America invasion (in current time). In the quote below, even though the agriculture department claims that they distribute certified seeds to the farmers, the distributed seeds are composed of mixed seeds (a mixture of many different types of seeds/not one type) or in some cases not certified at all. This has affected the production of wheat crop. Regarding the existence of financial corruption in agriculture sector during the America invasion, a cooperative member (Cooperative Member 4) from Logar province said:

"Our country has been destroyed by corruption. The 
agriculture ministry makes a contract with private companies but does not monitor it (contract). Currently, there is one laboratory for seed verification in FAO office where every company can easily get a voucher for the verification of their seeds by giving bribery. For cultivation purposes, farmers received wheat crop grain/ edible which was labeled as verified seeds by FAO's laboratory. However, the seeds are attacked by rusts once the farmers cultivated them" (Cooperative Member 4, September 4).

Besides wheat seeds, financial corruption exists in other agriculture related inputs businesses such as pesticides and chemical fertilizers. A cooperative member (Cooperative Member 6) from Kunduz province complained about the low quality of inputs available in the market during the America invasion. He added:

"We have a major issue of plant disease. It exists due to the low-quality pesticides in the market as a result of corruption... when we buy pesticides outside the bazaar, it has no quality. We pay for it (pesticides); we take and use it, but it has no quality and effects on diseases" (Cooperative Member 6, September 21).

\section{Discussion}

This study revealed that the wheat crop industry's players (farmers, extension officers, and cooperative members) are vulnerable in wheat crop production, delivery of extension services, and trade of wheat crop in the war zone which are discussed below.

Afghanistan has been going through four decades of war and conflict which includes of Soviet invasion (1979 -1989), civil war (1989-2001), and American invasion (2001 up to date). Besides infrastructure destruction and human causalities war severely affected farmers and damaged the agriculture sector. The long-lasting war made farmers susceptible to turbulences. Johanson and Johanson (2006) referred to turbulence as encountering unplanned situation and radical uncertainty that cannot be predicted in advance. Christopher and Holweg (2011) perceive turbulence as an inherently unstable and changing environment. Turbulence has been defined by Pettit et al. (2010) as an "environment characterized by frequent changes in external factors beyond your control". This study demonstrated that geopolitical disruptions, fluctuations in prices, and pandemic as a result of war are frequently happening in war zones which cannot be controlled by farmers. It is found that in the war zone, turbulence is more about the omnipresence of militants (Mujahedeen/Taliban/Troops), the high price of inputs, low prices for output, contamination of land, and lack of control of pesticides quality.
Besides turbulence, deliberate threats also make wheat crop industry players vulnerable in the war zone. Salafsky et al. (2008) referred to threats as the proximate human activities or processes that have induced, are inducing, or may result in the devastation, deterioration and/or dysfunction of biodiversity targets (e.g. unsustainable fishing or logging). There may be past (historical), ongoing, and/or likely future threats. Natural phenomena are also considered, in some situations, as direct threats. Sobel et al. (2002) describe deliberate threats from the biological perspective and argue that deliberate threat is the deliberate contamination of food with biological agents by terrorists. Deliberate attacks intended at interrupting or resulting in human or economic damages. Deliberate threats are "intentional attacks aimed at disrupting operations or causing human or financial harm" (Pettit et al., 2010). Deliberate threats such as terrorism/sabotage, theft, and special interest groups are the direct outcomes of war which is found as the main sub-factors of deliberate threats through this study. This study revealed that terrorizing people to migrate, kidnap of extension officers/aid workers, destruction of properties (agriculture offices), seizing civilian properties for military purposes, collection of illegal ransoms, and the existence of robbery cases related to drug addicts and militant groups are kinds of deliberate threats that happen in the war zone.

External pressure on wheat crop industry players constrains wheat crop industry development in the war zone. "External pressure is influence, not specifically targeting the firm, that creates business constraints or barriers" (Pettit et al., 2010). The findings of our study are aligned with Pettit et al. (2013) that external pressure is one of the highest vulnerabilities facing a diverse group of entities. This study exhibited that social changes, price pressures, and environmental changes are the common sub-factors of external pressure that exist more often in the war zone. The findings also agree with Kah (2017) that war causes social changes. Social changes are rapid changes in a society that arise from political transformation, economic crisis, or technological change (Kim and $\mathrm{Ng}, 2008$ ), population growth, patterns of migration, conflict, medical services, and contact patterns (Petney, 2001). Further, the study revealed that war cut traders' access to farmers and farmers access to markets. The inaccessibility severely affects both farmers and consumers through increasing price and creating price pressure in the war zone. In this case, farmers are forced to sell their products at lower prices while consumers should buy at a higher price. According to Zhu and Malhotra (2008), price pressure is a diverge from equilibrium level which is caused by a sudden imbalance between demand and supply and 
generate abnormal returns. The results of this study concur with Verpoorten (2009) found that cattle prices dropped significantly to less than half of their pregenocide value during the year of ethnic violence in Rwanda. While external pressure is defined as business constrain (Pettit et al., 2010) and rapid social changes (Kim and $\mathrm{Ng}, 2008$ ) in literature, external pressure is about mass migration, high price for farm's equipment, inaccessibility to output market, and the existence of war remnants (i.e. gun powders) in the war zone.

The agriculture sector faces resource limits in the war zone. "Resource limits are constraints on output based on the availability of the factors of production" (Pettit et al., 2010). Farmers often face resource limits through lower production capacity, lack of raw material (agricultural inputs such as seeds, water, and fertilizers), and human resources in the war zone. In the context of war, the resource limit is more about road blockade due to war, usage of traditional technologies, the existence of casualties, and lack of production resources. Due to inaccessibility to improved technologies/agricultural inputs (certified seeds, chemical fertilizer) in the war zone, farmers use traditional technologies and are involved in subsistence farming which has lowered their production capacity. The findings of this study are aligned with Adelaja and George (2019) that conflict is found to decrease men and women's working hours as hired labour. The agriculture sector is exposed to a shortage of labour because most of the labour flee the war zone due to human causalities.

Currently, sensitivity is turned to be a crucial issue in war-torn Afghanistan. "Sensitivity is the importance of carefully controlled conditions for product and process integrity" (Pettit et al., 2010). It is found that farmers are very sensitive to equipment reliability (agriculture inputs' quality) and safety hazard (farmers' safety) in the war zone. Sensitivity is more related to the existence of low-quality agriculture inputs and life danger in the war zone. The quality of agriculture inputs directly affects agriculture production. Four decades of continuous war and instabilities resulted in low quality of agriculture inputs. Due to war and instability, quality control is considered to be a hard job for agricultural ministry particularly in remote areas or areas out of government control. In addition, the existence of financial corruption in governmental administrations, paved the way for the availability of low-quality agricultural inputs in markets. Besides inputs' quality, farmers safety is also an issue in the war zone. This study agreed with the findings of Adelaja and George (2019) that security risks (life hazard) could prevent farmers from leaving their villages and working in remote farm fields due to frequent occurrences of violent conflict. This scenario affects timely farming (planting, irrigation, weeds control, and harvesting) activities which result in lower productivity and diminishing output.

The existence of connectivity between the farmers community and the agriculture department make the wheat crop industry more resilient in the active war zone. However, the lack of connectivity between farmers and the department of agriculture in the war zone, makes farmers vulnerable in agriculture production. "Connectivity is a degree of interdependence and reliance on outside entities" (Pettit et al., 2010). Through data analysis, it was found that connectivity concern the scale of the network, and reliance upon speciality sources in the war zone. Connectivity refers to the ability of an organization to collect and share information through the use of ICTs (information and communication technologies) (Fawcett et al., 2011). Connectivity facilitates capacity building (Wu et al., 2006). This study confirms the findings of Pettit et al. (2013) that connectivity is the highest vulnerability faced by a diverse group of companies. Connectivity is related to the existence/lack of extension services, and reliance upon agriculture department/inputs' suppliers in the war zone. This study found that farmers in the war zone are less organized and most often do not have a connection with the department of agriculture in order to support them in needed time. Thus, this leaves farmers vulnerable to a lack of inputs in the needed time.

In addition to the above-mentioned vulnerability constructs, the agriculture sector faces customer/supplier disruption in the war zone. "Customer/supplier disruption is the susceptibility of suppliers and customers to external forces or disruptions" (Pettit et al., 2010). The construct of supplier/customer disruption can be seen through the existence of sub-constructs of supplier reliability and customer disruption in the war zone. In the war zone, customer/supplier disruption explains lack of traders/buyers' relationship with farmers/producers and unreliability on inputs and food suppliers. This study confirms the findings of Hitzhusen and Jeanty (2006) that conflict/war interrupt both input and output markets. They further argue that food supplies are not just disrupted in the war zone, but also in adjacent areas. The devastation of bridges, roads and communications networks results in reduced market access, thus disrupting the mechanism of supply (Adelaja and George, 2019). Kah (2017) revealed that the markets were closed and custom duties dwindled due to the Boko Haram insurgency. He further argues that due to the ongoing conflict, fear of suicide bombers, trade of agricultural commodities has been seriously affected, supplies to other regions have been irregular and market cannot be held. 


\section{Conclusion}

The findings of this study revealed that farmers in the war zone are vulnerable to all seven vulnerability factors of supply chain resilience factors. These framework are included of turbulences, deliberate threats, external pressure, resource limits, sensitivity, connectivity and customer/supplier disruption. In addition to the vulnerability factors of the framework, the study found two new factors which were not existing in the framework. These factors are included of Psychological Effects/Fear and Financial Corruption.

Based on the study findings, it is advised to provide extension services, credit, inputs subsidies, agriculture machineries and advanced agriculture technologies to farmers in the war zone. The government should be accurate in the military operation against their armed opposition in order to prevent farmers from migrating/ abandoning their farms/villages which will avoid labor shortage in the agriculture sector. Agriculture agencies should help farmers in accessing the output market and build cool storages to enable farmers in preserving their produces off-season. The government should be committed in eradicating financial corruption which will assist in the improvement of inputs quality, decrease incidence of plant diseases and enhance crop productivity. Lastly, establishing farmers' cooperative is recommended which enables farmers to be organized, act independently in solving their problems by themselves and facilitate the delivery of extension services to the farmers.

\section{Conflict of interest}

There is no conflict of interest among all the authors.

\section{Acknowledgements}

The author is grateful to the Ministry of Higher Education of Afghanistan and Higher Education Development Project (HEDP) for funding the study.

\section{References}

Adelaja, A. and George, J. (2019). Effects of conflict on agriculture: Evidence from the Boko Haram insurgency. World Development, 117, 184-195. https://doi.org/10.1016/j.worlddev.2019.01.010

Adger, W.N. (2006). Vulnerability. Global Environmental Change, 16(3), 268-281. https:// doi.org/10.1016/j.gloenvcha.2006.02.006

Anaglo, J.N., Boateng, S.D. and Boateng, C.A. (2014). Gender and access to agricultural resources by smallholder farmers in the Upper West Region of
Ghana. Journal of Education and Practice, 5(5), 1319.

Awodola, B. and Oboshi, A. (2015). Terrorism in Northern Nigeria: A threat to food security in Maiduguri. Mediterranean Journal of Social Sciences, 6, 11-17. https://doi.org/10.5901/ mjss.2015.v6n3s2p11

Central Statistics Organization (CSO). (2019). Afghanistan Statistical Yearbook (2017-2018). (Issue No. 39): Retrieved on February 17, 2020 from CSO website: https://www.nsia.gov.af:8080/wpcontent/uploads/2019/04/Afghanistan-StatisticalYear-book-2017-18-3.pdf

Chabot, P. and Dorosh, P.A. (2007). Wheat markets, food aid and food security in Afghanistan. Food Policy, 32(3), 334-353. https://doi.org/10.1016/ j.foodpol.2006.07.002

Christopher, M. and Holweg, M. (2011). Supply Chain 2.0: managing supply chains in the era of turbulence. International Journal of Physical Distribution and Logistics Management, 41(1), 6382. https://doi.org/10.1108/09600031111101439

Fawcett, S.E., Wallin, C., Allred, C., Fawcett, A.M. and Magnan, G.M. (2011). Information technology as an enabler of supply chain collaboration: a dynamiccapabilities perspective. Journal of Supply Chain Management, 47(1), 38-59. https://doi.org/10.1111/ j.1745-493X.2010.03213.X

Gallopín, G.C. (2006). Linkages between vulnerability, resilience, and adaptive capacity. Global Environmental Change, 16(3), 293-303. https:// doi.org/10.1016/j.gloenvcha.2006.02.004

Girabi, F. and Mwakaje, A. (2013). Impact of Microfinance on Smallholder Farm Productivity in Tanzania: The Case of Iramba District. Asian Economic and Financial Review, 3(2), 227. https:// doi.org/10.4102/jamba.v2i2.17

Gwimbi, P. (2009). Cotton farmers' vulnerability to climate change in Gokwe District (Zimbabwe): impact and influencing factors. JAMBA: Journal of Disaster Risk Studies, 2(2), 81-92.

Harvey, C.A., Rakotobe, Z.L., Rao, N., Dave, R., Razafimahatratra, H., Rabarijohn, R.H., Rajaofara, H. and MacKinnon, J.L. (2014). Extreme vulnerability of smallholder farmers to agricultural risks and climate change in Madagascar. Philosophical Transactions of the Royal Society B: Biological Sciences, 369, 20130089. https://doi.org/10.1098/rstb.2013.0089

Hitzhusen, F.J. and Jeanty, P.W. (2006). Analyzing the effects of conflicts on food security in developing countries: An instrumental variable panel data 
approach presented at the 2006 Annual meeting, July 26-26. Long Beach, USA: American Agricultural Economics Association.

Ibrahim, S.S. and Aliero, H.M. (2012). An analysis of farmers access to formal credit in the rural areas of Nigeria. African Journal of Agricultural Research, 7 (47), 6249-6253. https://doi.org/10.5897/ AJAR 11.788

Jaafar, H.H., Zurayk, R., King, C., Ahmad, F. and AlOuta, R. (2015). Impact of the Syrian conflict on irrigated agriculture in the Orontes Basin. International Journal of Water Resources Development, 31(3), 436-449. https:// doi.org/10.1080/07900627.2015.1023892

Johanson, M. and Johanson, J. (2006). Turbulence, discovery and foreign market entry: A longitudinal study of an entry into the Russian market. Management International Review, 46(2), 179-205. https://doi.org/10.1007/s11575-006-0044-3

Kah, H.K. (2017). Boko Haram is losing, but so is food production: conflict and food insecurity in Nigeria and Cameroon. Africa Development, 42(3), 177-196.

Kim, J. and Ng, S.H. (2008). Perceptions of social changes and social identity: Study focusing on Hong Kong society after reunification. Asian Journal of Social Psychology, 11(3), 232-240. https:// doi.org/10.1111/j.1467-839X.2008.00262.x

Liverpool-Tasie, L.S.O. (2014). Farmer groups and input access: When membership is not enough. Food Policy, 46, 37-49. https://doi.org/10.1016/ j.foodpol.2014.01.006

McCarthy, J.J., Canziani, O.F., Leary, N.A., Dokken, D.J. and White, K.S. (Eds.). (2001). Climate change 2001: impacts, adaptation, and vulnerability: contribution of Working Group II to the third assessment report of the Intergovernmental Panel on Climate Change. Vol. 2. United Kingdom: Cambridge University Press.

Owolabi, J.O., Abubakar, B.Z. and Amodu, M.Y. (2011). Assessment of Farmers (Women) Access to Agricultural Extension, Inputs and Credit Facility in Sabon-Gari Local Government Area of Kaduna State. Nigerian Journal of Basic and Applied Sciences, 19(1), 87-92. https://doi.org/10.4314/ njbas.v19i1.69350

Peck, H. (2006). Reconciling supply chain vulnerability, risk and supply chain management. International Journal of Logistics: Research and Applications, 9 (2), 127-142. https:// doi.org/10.1080/13675560600673578

Persaud, S. (2013). Afghanistan's Wheat Flour Market: Policies and Prospects. Retrieved from the USDA website:

https://www.ers.usda.gov/webdocs/ outlooks/39902/40369 whs-13i-01.pdf?v=196.4

Petney, T.N. (2001). Environmental, cultural and social changes and their influence on parasite infections. International Journal for Parasitology, 31(9), 919-932. https:// doi.org/10.1016/S0020-7519(01)00196-5

Pettit, T.J., Fiksel, J. and Croxton, K.L. (2010). Ensuring supply chain resilience: development of a conceptual framework. Journal of Business Logistics, 31(1), 121. https://doi.org/10.1002/j.21581592.2010.tb00125.x

Pettit, T.J., Croxton, K.L. and Fiksel, J. (2013). Ensuring supply chain resilience: development and implementation of an assessment tool. Journal of business logistics, 34(1), 46-76. https:// doi.org/10.1111/jbl.12009

Salafsky, N., Salzer, D., Stattersfield, A.J., HiltonTaylor, C., Neugarten, R., Butchart, S.H.M., Collen, B., Cox, N., Maser, L.L., O'Connor, S. and Wilkie, D. (2008). A standard lexicon for biodiversity conservation: unified classifications of threats and actions. Conservation Biology, 22(4), 897-911. https://doi.org/10.1111/j.1523-1739.2008.00937.x

Shiferaw, B.A., Kebede, T.A. and You, L. (2008). Technology adoption under seed access constraints and the economic impacts of improved pigeon-pea varieties in Tanzania. Agricultural Economics, 39 (3), 309-323. https://doi.org/10.1111/j.15740862.2008.00335.x

Sobel, J., Khan, A.S. and Swerdlow, D.L. (2002). Threat of a biological terrorist attack on the US food supply: the CDC perspective. The Lancet, 359 (9309), 874-880. https://doi.org/10.1016/S01406736(02)07947-3

Thorlakson, T. and Neufeldt, H. (2011). Reducing subsistence farmers' vulnerability to climate change: the potential contributions of agroforestry in western Kenya. Agriculture and Food Security, 1, 15. https:// doi.org/10.1186/2048-7010-1-15

United States Agency for International Development (USAID). (2020). Food Assistance Fact Sheet, Afghanistan. Retrieved on June 20, 2020 from USAID website: https://www.usaid.gov/afghanistan/ food-assistance

Verpoorten, M. (2009). Household coping in war-and peacetime: Cattle sales in Rwanda, 19912001. Journal of Development Economics, 88(1), 67 -86. https://doi.org/10.1016/j.jdeveco.2008.01.003

Wesa, T. (2002). The Afghan agricultural extension system: impact of the Soviet occupation and prospects for the future. Canada: University of 
British Columbia, $\mathrm{PhD}$ dissertation.

World Bank. (2005). Poverty, Vulnerability, and Social Protection in Afghanistan: An Initial Assessment. Report No. 29694-AF. Washington, DC., USA: World Bank.

World Bank. (2014). Revitalizing Agriculture Sector for Economic Growth, Job Creation and Food Security. Report No: AUS9779. Retrieved on March 20, 2020 from World Bank's website: http:// documents1.worldbank.org/curated/ en/245541467973233146/pdf/AUS9779-REVISEDWP-PUBLIC-Box391431B-Final-Afghanistan-ASRweb-October-31-2014.pdf

Wu, F., Yeniyurt, S., Kim, D. and Cavusgil, S.T. (2006). The impact of information technology on supply chain capabilities and firm performance: A resourcebased view. Industrial Marketing Management, 35 (4), 493-504. https://doi.org/10.1016/ j.indmarman.2005.05.003

Zarafshani, K., Sharafi, L., Azadi, H., Hosseininia, G., De Maeyer, P. and Witlox, F. (2012). Drought vulnerability assessment: The case of wheat farmers in Western Iran. Global and Planetary Change, 9899, 122-130. https://doi.org/10.1016/ j.gloplacha.2012.08.012

Zhu, P. and Malhotra, S. (2008). Announcement effect and price pressure: An empirical study of crossborder acquisitions by Indian firms. International Research Journal of Finance and Economics, 13(1), 24-41. 